Karstenia 43: 9-12, 2003

\title{
A note on the claimed toxicity of Cortinarius gentilis
}

\author{
EEVA-LIISA HINTIKKA and MAURI KORHONEN
}

\begin{abstract}
Hintikka, E.-L. \& Korhonen, M. 2003: A note on the claimed toxicity of Cortinarius gentilis. - Karstenia 43: 9-12. Helsinki ISSN 0453-3402.

The toxicity of Cortinarius orellanus group of mushrooms became apparent in the 1950ies. C. gentilis was considered toxic in Finnish mycological publications. The opinion was primarily based on the study by Möttönen et al. (1975) and on a case study by Hulmi et al. (1975), which papers were then cited in later publications. When the specimens on which the first-named study was based were rechecked, it turned out that the original material used for the rat feeding test by Möttönen with his co-workers was not adequately documented. In order to examine the possible toxicity of Finnish C. gentilis mushrooms, the present authors studied 28 samples of this species. An unspecific cell culture toxicity test and a feeding test on mice revealed no toxicity in C. gentilis.
\end{abstract}

Key words: Cortinarius gentilis, toxicity

Eeva-Liisa Hintikka, Finnish Institute of Occupational Health, Uusimaa Regional Institute, Arinatie 3 A, FIN-00370 Helsinki, Finland

Mauri Korhonen, Botanical Museum (Mycology), P.O. Box 7, FIN-00014 University of Helsinki, Finland

\section{Introduction}

The toxicity of the fleshy fungus Cortinarius orellanus Fr. became apparent in 1952 when 102 people in Poland fell ill after consuming this fungus. In this outbreak eleven people died 4-16 days after the meal due to the acute renal failure (Wieland 1996). This severe outbreak brought fear for the toxicity of Cortinarius fungi and this genus of mushrooms was suddenly regarded by general public to be very toxic and not edible at all. Research work was directed to find out toxic Cortinarius species and to develop analytical toxicological methods (Tebbett \& Caddy 1983, 1984). A surprisingly long latency period was reported, more than two weeks, between the ingestion of toxic Cortinarius mushrooms and the appearance of the clinical symptoms, which makes difficult to diagnose field cases. Schumacher and Høyland (1983) published a detailed documentation of Cortinarius poisonings. Keller-Dilitz et al. (1985) introduced a thin layer chromatography method to show the presence of orellanine, the main toxic compound in Cortinarius mushrooms. In addition to $C$. orellanus, $C$. speciosissimus was soon found to contain orellanine as well.

Recent taxonomic and nomenclatural studies on Cortinarius have changed the name of $C$. speciosissimus and modern DNA techniques have brought new information on Cortinarius phylogeny (Høyland \& Holst-Jensen 2000). C. speciosissimus is now called $C$. rubellus Cooke, synonyms: C. speciosissimus Kühner\& Romagn. and $C$. orellanoides Rob. Henry (Brandrud et al. 1990). Its toxicity is well known and confirmed (Brandrud et al. 1990, Svendsen et al. 2002). C. rubellus has caused poisonings even to animals (Överås et al. 1979).

The aim of this paper is to re-evaluate the toxicity of Cortinarius gentilis (Fr.) Fr. The original mushroom material used in a Finnish animal experiment (Möttönen et al. 1975) was rechecked and a new toxicity study on $C$. gentilis was carried out. 


\section{Literature review on toxicity of Cortinarius gentilis}

Cortinarius gentilis is not reported to be toxic according to an extensive literature survey (Danel et al. 2001), except in the Finnish paper by Möttönen et al. (1975). Another Finnish publication (Hulmi et al. 1974) has been interpreted to support the toxicity of $C$. gentilis. We shall examine these two papers more closely They have often been referred in international literature (Tebbet \& Caddy 1984, Prast et al. 1988, Bresinsky \& Besel 1985). Based on these papers many popular mushroom guides, at least in Finland, have considered $C$. gentilis toxic in addition to $C$. rubellus and C. orellanus.

Hulmi et al. (1974) described in a Finnish medical journal a case where four persons, viz. the parents, grandmother and an 8-year old son fell seriously ill after a meal prepared of wild mushrooms. A part of the mushrooms had been frozen fresh, another part boiled before freezing. Most mushrooms represented Boletus, but among them were some additional mushrooms. According to the authors they did not know what species were eaten and whether the studied mushrooms were boiled or not before freezing. They suggested in their abstract, written only in Finnish, that Cortinarius speciosissimus (i.e., C. rubellus) might have caused the poisoning. The paper describes the symptoms, the laboratory experiments, the treatments in hospitals and the follow-up of the patients up to one year. The father was most seriously ill, but recovered after a kidney transplant.

\section{Cortinarius gentilis sample used by Möttönen et al. (1975)}

The results of the feeding experiment by Möttönen et al. (1975), are likely partly based on a wrong species identification or mixing of two specimens. The herbarium specimen of C. gentilis Fr., HH. No. 72, Kuopio, which Möttönen et al. referred in their paper, and which was used as feeding material for the rats in their experimental study, was found in the Kuopio Collection under two names. The name $C$. speciosissimus is written on the outer cover of that specimen and the name $C$. gentilis written on the inner cover of the same specimen. The material used for feeding experiment as $C$. gentilis mushrooms encompasses specimens of two species and is therefore not satisfactorily documented.

\section{Toxicity studies of Cortinarius gentilis by cell culture and feeding test on mice}

\section{Mushroom samples}

Cortinarius gentilis Fr. samples were collected in South Finland, Tammisaari, Raasepori, Repubacka, on sandy heath coniferous forest on 28th September 1990 (Mauri Korhonen 10004, H) and deep-frozen on the following day.

\section{Toxicity studies}

The toxicity of the Cortinarius gentilis samples was studied by two methods. All mushroom samples were first studied by a method in which an extract from every single fruitbody was individually tested in a cell culture system. Altogether 28 C. gentilis samples were studied by this method, which can be regarded as an unspecific screening test for materials e.g. too small for feeding tests. The main toxicity test was a feeding experiment on mice for studying especially the possible effects on the kidneys.

\section{Cell culture toxicity test}

The size of the Cortinarius gentilis fruitbodies varied. A sector of the cap weighing 1.3-3.0 g was cut for cell culture toxicity test. Small caps were used as whole, and the smallest samples in those cases weighed $0.6 \mathrm{~g}$. The material was ground in a mortar and physiological salt water added; $3.0 \mathrm{ml}$ of water to $1.3 \mathrm{~g}$ sampel. The samples were kept for two hours at $+4^{\circ} \mathrm{C}$, centrifugized at $3200 \mathrm{r} / \mathrm{min}$. The supernatant was filtered and studied on U-cell cultures according to the method described in Hintikka (1978). The death of the cells is regarded as indicator of toxic substance extracted from the original material. The detailed method of toxicity test is described by Nikulin and co-workers (Pasanen et al. 1993). All tests were carried out twice. Out of the 28 C. gentilis samples 26 were non-toxic and two showed slightly toxic regarded rather to be caused by the raw extract of the mushroom material, not by a specific toxin.

\section{Feeding test to mice}

Five grams of mushroom materials combined from about five Cortinarius gentilis samples were ground and mixed in $25 \mathrm{~g}$ of mice diet and fed to a group of five mice. Each mouse was supposed to eat about one gram of the original $C$. gentilis material. There were three experimental groups with $C$. gentilis mushrooms and a control group. The mice weighed $25 \pm 2 \mathrm{~g}$ in the beginning of the experiment. After the mice had finished their mushroom feeds the diet turned to the former mice ration. Animals had free access to water. The mice showed no symptoms for disease After seven days they were killed. The post mortem examinations revealed normal findings and the histopathology of the liver and kidney samples shoved no pathological changes. 


\section{Discussion}

Since 1970ies with confusion on the poisonous Cortinarius species the methods to analyze chemically mushroom toxins have developed. Oubrahim et al. (1997) describes three methods for identification and quantification of orellanine, the main toxin, from several Cortinarius species. According to Oubrahim et al. classical TLC or electrophoresis coupled with electron spin resonance are sensitive enough methods to detect orellanine.

In the rat experiment by Möttönen et al. (1975) the renal weight, serum urea value and microscopically demonstrated renal lesions were used as criteria for toxic effect caused by the mushrooms. Rats fed with $C$. rubellus showed variations by these criteria, even severe lesions in kidneys were found. Among the rats fed with $C$. gentilis material only one rat out of six animals showed some changes in the histological examination of the kidneys but no differences in the serum urea values. The microscopically demonstrated renal lesions of this rat were mild according to the authors. One may suggest that a possible mixing of material of $C$. gentilis with that of $C$. speciosissimus could explain the results gained by their animal experiment.

The toxicity studies in the cell culture test and the feeding test on mice gave no hints that Finnish $C$. gentilis is toxic. Experiments carried out on different animal species are not directly comparable, but on the other hand mice are used in similar toxicity studies of Cortinarius species (Prast et al. 1988).

It is concluded that an unfortunate mixing of material of two Cortinarius species and the difficulties to quote a paper written only in Finnish language may have been misleading to the later reports that Cortinarius gentilis is toxic. Until today no evidence is found that Finnish $C$. gentilis is toxic and thereby differs from the same species from other countries.

Recent taxonomic studies (Høyland \& HolstJensen 2000) have shown that $C$. gentilis and $C$. rubellus belong to different phylogenetic groups. C. gentilis is a member of the subgenus Telamonia and related to C. brunneus. C. rubellus belongs to the subgenus Cortinarius but has no close relatives.

\section{References}

Bresinsky, A., Besel, H.1985: Giftpilze, Ein Handbuch fur Apotheker, Ärzte und Biologen: 57-58. - Wissenschaftliche Verlagsgesellschaft mbtt, Stuttgart.

Brandrud, T.E., Lindström. H., Marklund, H., Melot, J. \& Muskos, H. 1990: Cortinarius, Flora Photographica. - Photoflora, $40 \mathrm{pp}+$ plates. Publ. by Cortinarius Ho, Matfors, Sweden.

Danel, V.C., Saviuc, P.F. \& Garon, D. 2001: Main features of Cortinarius spp. poisoning: a literature review. - Toxicon 39: 1053-1060.

Hintikka, E.-L. 1978: Toxicity of mushroom samples in cell culture system. - Karstenia 18 (suppl.): 40-42.

Hulmi, S., Sipponen, P., Forström, J. \& Vilska, J. 1974: Seitikkisienen aiheuttama vakava munuaisvaurio. [Mushroom poisoning caused by Cortinarius speciosissimus. A report of four cases.] - Duodecim 90: 1044-1055.

Høyland, K. 1985: Is Cortinarius orellanoides an earlier name for C. speciosissimus? - Nord. J. Bot. 5: 489492.

Høyland, K. \& Holst-Jensen, A. 2000: Cortinarius phylogeny and possible taxonomic implications of ITS rDNA sequences. - Mycologia 92: 694-710.

Keller-Dilitz, H., Moser, M. \& Ammirati, J.H. 1985: Orellanine and other fluorescent compounds in the genus Cortinarius section Orellani. - Mycologia 77 : 667-673.

Möttönen, M., Nieminen, L. \& Heikkilä, H. 1975: Damage caused by two Finnish mushrooms, Cortinarius speciosissimus and Cortinarius gentilis on the rat kidney. - Z. Naturforsch. 30C: 668-671.

Oubrahim, H., Richard, J.-M., Cantin-Esnault, D., Seigle-Murandi, F. \& Trècourt,F. 1997: Novel methods for identification and quantitation of the mushroom nephrotoxin orellanine. - J. Chromatogr. A, 758: 145 - 157.

Pasanen, A.L., Nikulin, M., Tuomainen, M., Berg, S., Parikka,P. \& Hintikka, E.-L. 1993: Laboratory experiments on membrane filter sampling of airborne mycotoxins produced by Stachybotrys atra Corda. Atmospheric Environment 27A: 9-13.

Prast, H., Werner, E.R., Phaller, W. \& Moser, M. 1988: Toxic properties of the mushroom Cortinarius orellanus. I, Chemical characterization of the main toxin of Cortinarius orellanus (Fries) and Cortinarius speciosissimus (Kuhn \& Romagn.) and acute toxicity in mice. - Arch Toxicol. 62: 81-88.

Schumacher, T. \& Høyland, K. 1983: Mushroom poisoning caused by species of the genus Cortinarius Fries. - Arch. Toxicol. 53: 87-106.

Svendsen, B.S., Gjellestad, A., Eivindson, G., Berentsen, G. \& Jacobsen, D. 2002: Alvorlige soppforgiftninger med giftslörsopper og hvit fluesopp. - Tidsskr. Norsk Lägeføren. 122: 777-80.

Tebbett, I.R. \& Caddy, B. 1983: Analysis of Cortinarius mushrooms by high-performance liquid chromatography. - J. Chromatogr. 268: 535-538.

Tebbett, I.R. \& Caddy, B. 1984: Mushroom toxins of the genus Cortinarius. - Experientia 40: 441-446. 
Wieland, T. 1996: Toxins and psychoactive compounds from mushrooms. - In Howard/Miller (eds), The mycota. VI. Human and animal relationships: 229-248. Springer-Verlag, Berlin \& Heidelberg.

Överås, J., Ulvund, M., Bakkevig, S. \& Eiken, R 1979: Poisoning in sheep induced by the mushroom Cortinarius speciosissimus. Brief communication. - Acta Vet. Scand. 20: 148-50. 